\title{
САНСРЫН ХОГ ХАЯГДЛЫН АЖИГЛАЛТ, СУДАЛГАА
}

\author{
Н.Тунгалаг, Т.Баярбат, Ц.Шижирбаяр, Д. Ундрах, Б.Отгонсүрэн, М.Батболд \\ ШУА, Одон орон геофизикийн судалгааны төв \\ Цахим шуудан: Namkhai_tungalag@yahoo.com
}

Абстракт. Астрофизикийн суурь судалгааны хөтөлбөрийн дагуу Монгол улсад анх удаа сансрын хог хаягдал, сансрын гамма тэсрэлтийн тогтмол ажиглалтууд хийгдэж эхэллээ. Энэ хөтөлбөрийн хүрээнд Одон орон геофизикийн судалгааны төвийн Хүрэлтогоот дахь одон орон судлах оргилд ORI-40, VT-78е дурангуудыг суурилуулан ажиллагаанд оруулсан. Одон орны тогтмол ажиглалт явуулснаар ОХУ-ын “Астрометрийн ба фотометрийн ажиглалтын оптик дурангуудын сүлжээ” олон улсын эрдэм шинжилгээний нээлттээи төсөлд хамрагдан ажиллаж байна [1,2].

Abstract. Regular astronomical observations for applied and astrophysical programs in particular space debris investigations, observations of asteroids and space gamma-ray bursts were started in Mongolia for the first time. The observations are possible after the installation of optical telescopes ORI-40 and VT-78a in observatory Hureltogoot.Therefore, the observatory is operating within the international network of astrometric and photometric instruments ISON (International Scientific Optical Network) located in Russian Federation [1,2].

\section{ОРШИЛ}

Геостационар тойрог зам дахь сансрын үйл ажиллагаатай холбогдож гарсан хог хаягдлууд, тухайлбал, ажиллагаагүй болсон сансрын аппарат, түүний эд ангиуд, пуужингийн угсраанууд ихсэхийн хэрээр идэвхтэй ажиллаж байгаа сансрын аппарат, хиймэл дагуулуудыг мөргөн гэмтээх, ажиллагаагүй болгох нөхцөл үүсч ирсэн. Иймээс 2007 оны 11-р сард хуралдсан НҮБ-ын Ерөнхий ассемблейн чуулганаар “Сансрын хог хаягдал үүсэхээс сэргийлэх Удирдах зарчим”-ыг баталж сансар дахь дахь аюулгүй ажиллагааны хэм хэмжээг тогтоох, сансрын хог хаягдлыг шинжлэн судлах шаардлага зүй ёсоор тавигдах болов. Үүнтэй уялдан олон улсын шинжлэх ухааны байгууллагууд сансрын хог хаягдлыг астрономийн аргаар дуран авайн тусламжтай ажиглах, бүртгэх, индексжүүлэх ажлыг эрчимтэй явуулж байна. Мөн эдгээр биетүүдийн хөдөлгөөний хувьсал, орон зай дахь тархалтыг тогтоон болзошгүй мөргөлдөөний магадлалыг ямар нэгэн нарийвчлалтай тодорхойлох боломжийг ч судалж байна. Том орнууд сансрын хог хаягдлыг уртрагийн дагуу тархан байрласан олон ажиглалтын цэгүүдээс ажиглан мэдээг нэгтгэж өндөр нарийвчлалтай үр дүнг гарган авах замаар судалгаа явуулж байна. Монгол улс ч өөрийн газар зүйн байрлалын хувьд ийм сүлжээнд нэгдэн орж ажиглалтын цэгийг байгуулан сансрын хог хаягдал, дэлхийн орчмын бага гарагийн ажиглалт явуулж байна.

\section{АРГАЧЛАЛ, АЖИГЛАЛТ, СУДАЛГАА}

Сансрын хог хаягдлыг радиолокацийн болон оптик ажиглалтын гэсэн үндсэн хоёр аргаарсудалдаг.Эдгээрээсоптикажиглалтын арга нь харьцангуй хямд өртөгтэй, судалгааны үр дүн нь радиолокацийн аргаас дутахгүй байдаг учраас одоо үед энэ судалгаанд астрономийн оптик дурангуудыг өргөн ашиглаж байна. Техникийн гаралтай сансрын хог хаягдлуудын бодит тархалт, үүсэл, хувьслын зүй тогтлыг урьдчилан 
таамаглах, болзошгүй мөргөлдөөний аюулаас сэргийлэх тооцоог хийхэд их хэмжээний ажиглалтын материал, шинэ шинэ хэмжилтүүд шаардагддаг. Одоогийн хуримтлагдсан мэдээллийг үзвэл өндөр орбит дахь хаягдлуудын талаарх мэдээлэл бага, улмаар тархац нь бага судлагдсан байгаа нь харагддаг. Өндөр орбит дахь бохирдлын судалгаагОХУ-д“Астрометрийн ба фотометрийн ажиглалтын оптик дурангуудын сүлжээ” гэсэн олон улсын эрдэм шинжилгээний нээлттэй төслийн хүрээнд ОХУ-ын ШУА-ийн Хавсарга математикийн хүрээлэн эрхлэн явуулдаг [3]. Энэ сүлжээ нь дэлхийн 10 оронд 19,2 см-ээс 2,6 м хүртэл голточтой дурангууд бүхий 26 ажиглалтын цэгтэй (1-р зураг) ба эдгээр ажиглалтын цэгүүд нь:

- геостационар тойрог замын мужид самналт хийх

- өндөр орбит дахь сансрын хог хаягдлын хэлтэрхийнүүдийг дагах

- сул гэрэлтэй объектуудыг судлах
- тод гэрэлтэй объектуудыг тусгайлан судлах

- бага гарагийн ажиглалт

- хиймэл дагуулын фотометрийн ажиглалт

гэсэн 6 үндсэн зорилтыг дурангийн хүчин чадал, зориулалтаасаа хамааран хэрэгжүүлж ажилладаг.

Сүлжээний үйл ажиллагааг:

- Оросын ШУА-ийн Хавсарга математикийн хүрээлэнгийн ажиглалтыг төлөвлөх, дүн шинжилгээ хийх групп

- “Проект-Техника" Астрономийн шинжлэх ухааны төвийн техник ба программ хангамжийг дэмжих групп

- Оптик дуран ба автомат суурины үйлдвэрлэлийн баг

- Крымийн одон орны оргилын ажиглалтын технологийн боловсруулалтын баг

ханган ажиллаж байна.

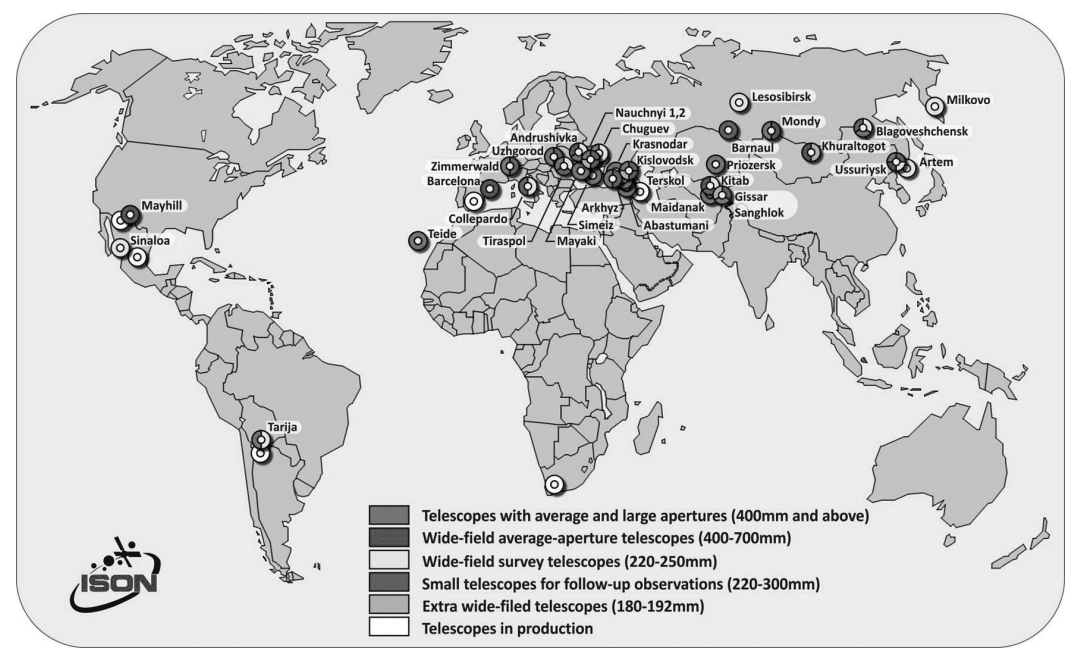

1-р зураг. Оптик дурангуудын сүлжээний газарзүйн байрлал

2012 онд Одон орон геофизикийн судалгааны төвийн Хүрэлтогоот дахь одон орны оргилд сансрын хог хаягдлын самналт ажиглалт болон бага гарагийн фотометрийн ажиглалт хийхэд зориулагдсан 40 см-ийн голточтой ORI-40, 19.2 см-ийн голточтой VT-78e (2-p зураг) дурангуудыг суурилуулан ажиглалт хийж эхэлснээр энэХүY “Астрометрийн ба фотометрийн ажиглалтын оптик дурангуудын сүлжээ”тэй нарны аймгийн жижиг биетийн ажиглалт, судалгааны чиглэлээр хамтран ажиллах болсон. Ажиглалтын зарчим нь тухайн шөнийн ажиглалтын хугацаанд 
дуран геостационар мужийн үзэгдэх хэсгийг өргөн зурвасаар 2 удаа самналт хийн $3 \times 3$ градусын талбай бүрт 10-15 секундын зураг авах байдлаар туулдаг. Энэ явцад 15.5 хүртэлх одны хэмжигдхүүнтэй объект бүрийн ажиглалтын нийт хугацаа ойролцоогоор 30 минут болдог нь каталогт бүртгэгдээгүй объектыг илрүүлж тойрог замыг нь зурах боломж олгодог. Энэ аргачлалыг Крымийн одон орны оргилын эрдэмтэд боловсруулсан ба сүлжээний самналт хийх зориулалттай бүх дурангуудад хэрэглэж байна [3]. Ажиглалтыг CamControl дуран удирдах автомат программ ашиглан хийдэг ба ажиглалтын зургуудыг APEXавтомат программ хангамжийн тусламжтай боловсруулан объектын тойрог замыг тодорхойлдог. Бүх программ хангамжийг “Проект-Техника"

Астрономийн шинжлэх ухааны төвийн техник ба программ хангамжийг дэмжих групп боловсруулсан болно. Самналт ажиглалт хийх төлөвлөгөөний зарчимыг 3-р зурагт үзүүлэв. Зураг дээр, мэдэгдэж байгаа бүх геостационар объектудын траекторийг харуулсан ба дуран ажиглалтын үеэр бүх траекторийг хоёр удаa туулах ёстой. Ингэхдээ дэлхийн сүүдрийн урд ба ар талд, өөрөөр хэлбэл фазын өнцгөөс шалтгаалан геостационар объектуудын гэрэл илүY тодордог тэр мужуудад үндсэн зургуудаа авдаг. Цэлмэг шөнө самналтын үеэр зуун гаруй геостационар объектуудыг ажиглаж болдог ба нийт сүлжээний хэмжээнд нэг шөнө хэд хэдэн дуран нийлээд 775 хүртэлх объектыг хянах боломжтой болдог. Энэ нь мэдэгдэж байгаа, каталогт бүртгэгдсэн объектуудын бараг тал хувь нь юм. Энэ маягаар самналт ажиглалт нь зөвхөн хуучин объектуудыг хянах биш шинээр үүссэн хог хаягдал, урьд мэдэгдээгүй каталогт бүртгэгдээгүй объектыг ч олж илрүүлэхэд чухалачхолбогдолтой.Сүлжээнийхэмжээнд сард 10-11 сул гэрэлтэй объектуудыг олж илрүүлдэг. ОХУ-ын Хавсарга математикийн хүрээлөнгийн өгөгдлийн санд одоогоор 7 сая гаруй хэмжилтийн материал цугларсан ба 3300 гаруй объектын тойрог зам, гэрэлтэл, гадаргуун талбайн массад харьцуулсан харьцаа зэрэг физик параметруудыг тодорхойлсон байна. Хуримтлагдсан мэдээллүүдийг геостационар муж дахь сансрын хог хаягдлуудын тархалт, хөдөлгөөний хувьслын загварыг нарийвчлахад ашиглаж байна.

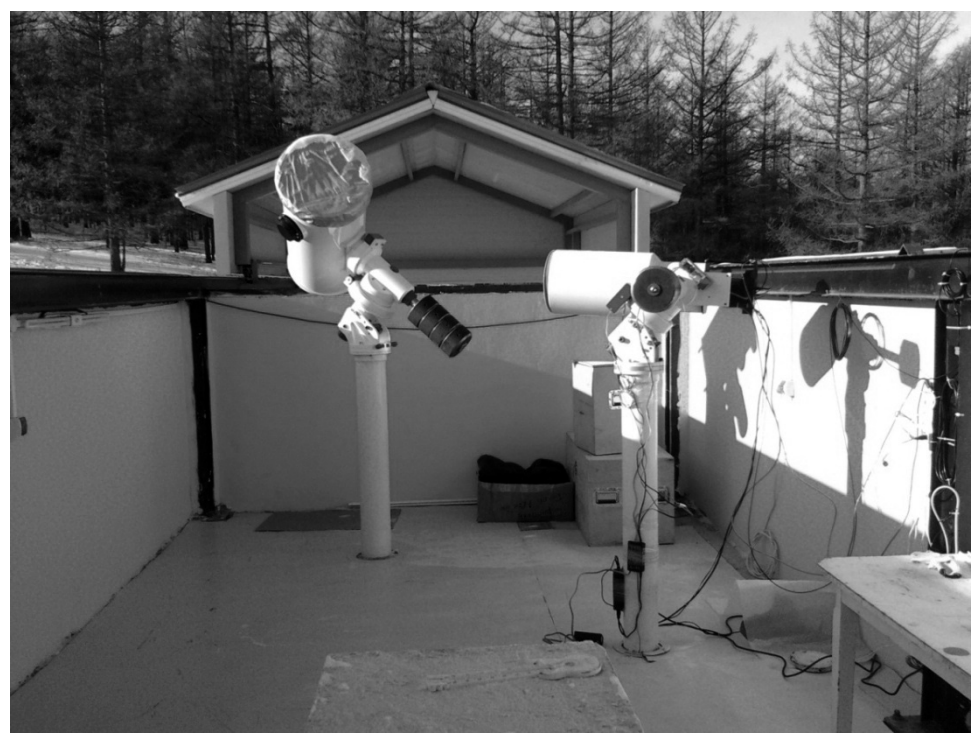

2-p зураг. ORI-40, VT-78е дурангууд 


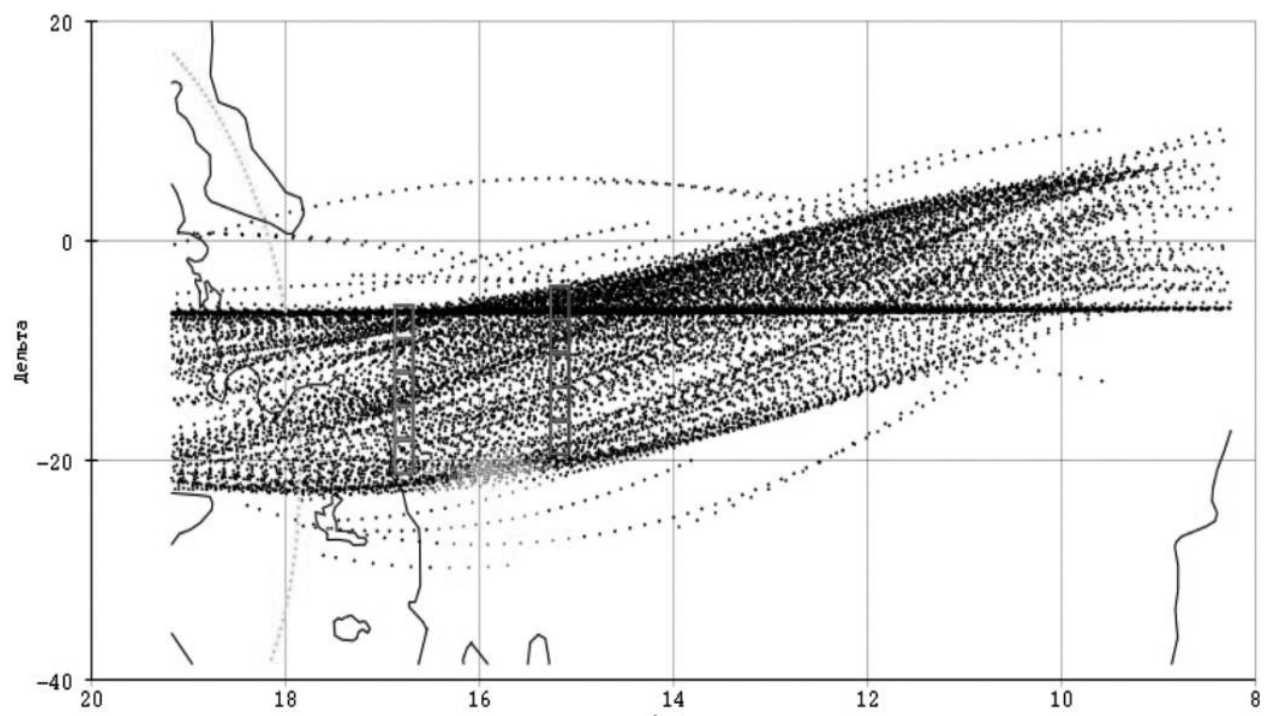

3-р зураг. Самналт ажиглалтын төлөвлөгөө. Хөх цэгүүд - мэдэгдэж байгаa бүх геостационар объектуудын траектори. Ногоон муж - Дэлхийн сүүдэр. Ягаан ба улаан дөрвөлжингүүд - дуран шөнийн турш самналт хийх мужууд.

\section{ҮР ДУН, ДУГНЭЛТ}

ООГСТ-ийн одон орны оргилд сансрын хог хаягдлын ажиглалтыг тогтмол явуулж ажиглалтын мэдээллийг дээр дурьдсан хүрээлэнгийн техникийн гаралтай сансрын объектуудын мэдээллийг цуглуулах, хадгалах, боловсруулах, дүн шинжилгээ хийх төвийн мэдээллийн санд илгээх болсон. Ингэснээр геостационар объектуудын динамик ба орбитал архивын байнгын идэвхитэй ажиллагааг дэмжиж тэдгээрийн хөдөлгөөний хувьсалыг дүгнэх, загварчлах, нарийвчлалыг сайжруулахад тодорхой хувь нэмэр болох юм.

2013 онд манай ажиглагчид нийт 120 орчим шөнө ажиглалт хийн 300000 орчим кадр зураг авч боловсруулалт хийсэн байна. Каталогт байгаагүй 2 объект (хог хаягдал) илрүүлж ИПМ90253, ИПМ90275 гэж дугаарласан.

Хүрэлтогоотын одон орны оргил нь далайн түвшнээс дээш 1620 м-ийн өндөрт байрладаг нь одон орны ажиглалт явуулахад нэн тохиромжтой. Хэдийгээр хотын гэрэл зургийн чанарт муугаар нөлөөлдөг боловч ажиглалтын үр дүнгүүдийг харахад манай зургийн чанар (seeing) хангалттай сайн гэж хэлж болох ба астроклимат сайтай гэж хэлэгддэг Санглокийн (Узбек) одон орны оргилын зургийн чанартай ойролцоо байгааг харж болно (4, 5-р зургууд) [3]. Цаашид ажиглалтыг үргэлжлүүлэн явуулна.

Энэхүу ажил нь ОССС-ийн 1101-92202-Монг-а төслөөр хэсэгчлэн дэмжигдсэн болно. Мөн, дурангийн болон ажиглалтын байр барих, компьютер тоног төхөөхөмжөөр хангах зэрэг энэ ажлыг хэрэгжүүлэх, ажиглалтыг эхлүүлэхэд нэн шаардлагатай дэмжлэг туслалцааг цаг тухайд нь үзүүлж ирсэн ООГСТ-ийн удирдлага, захиргаа, нийт хамт олонд гүн талархал илэрхийлж байна. 


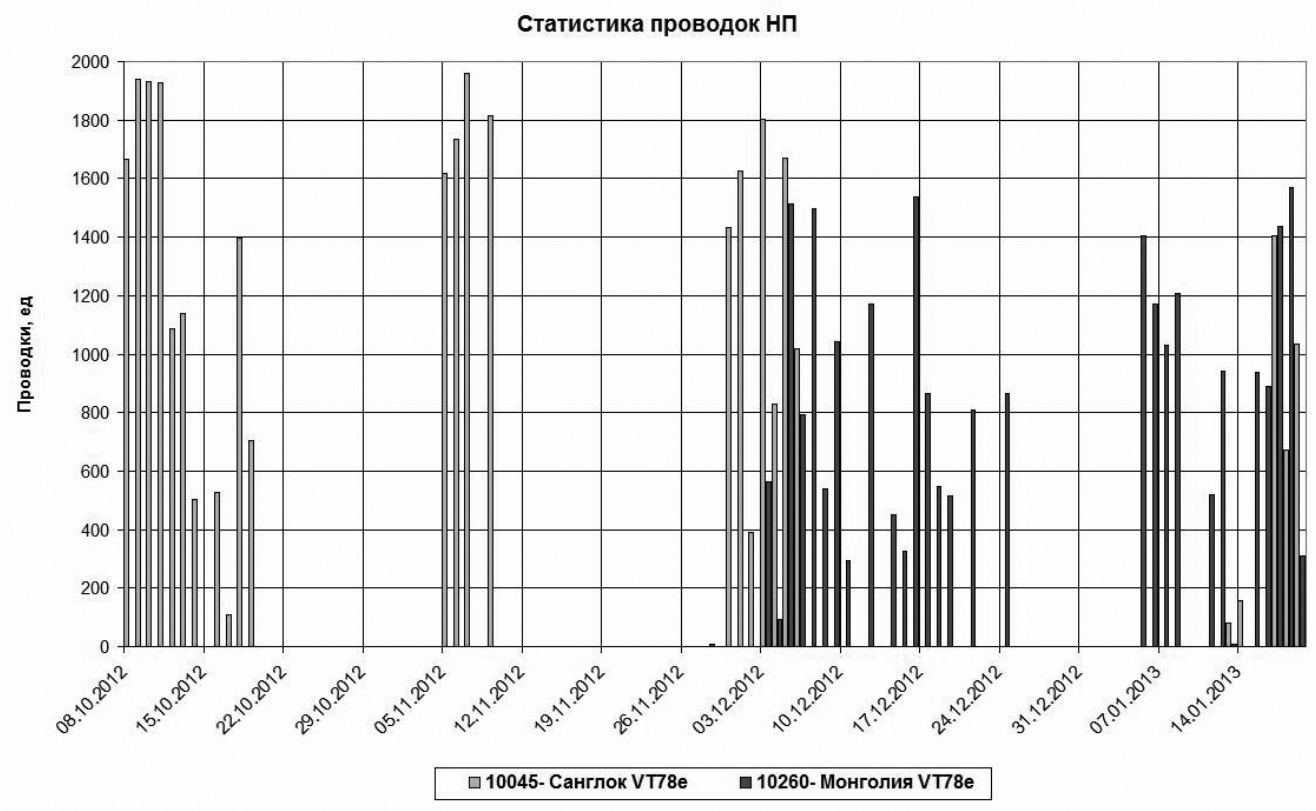

4-р зураг. Хүрэлтогоот ба Санглокын одон орны оргилуудын ажиглалтын статистик.

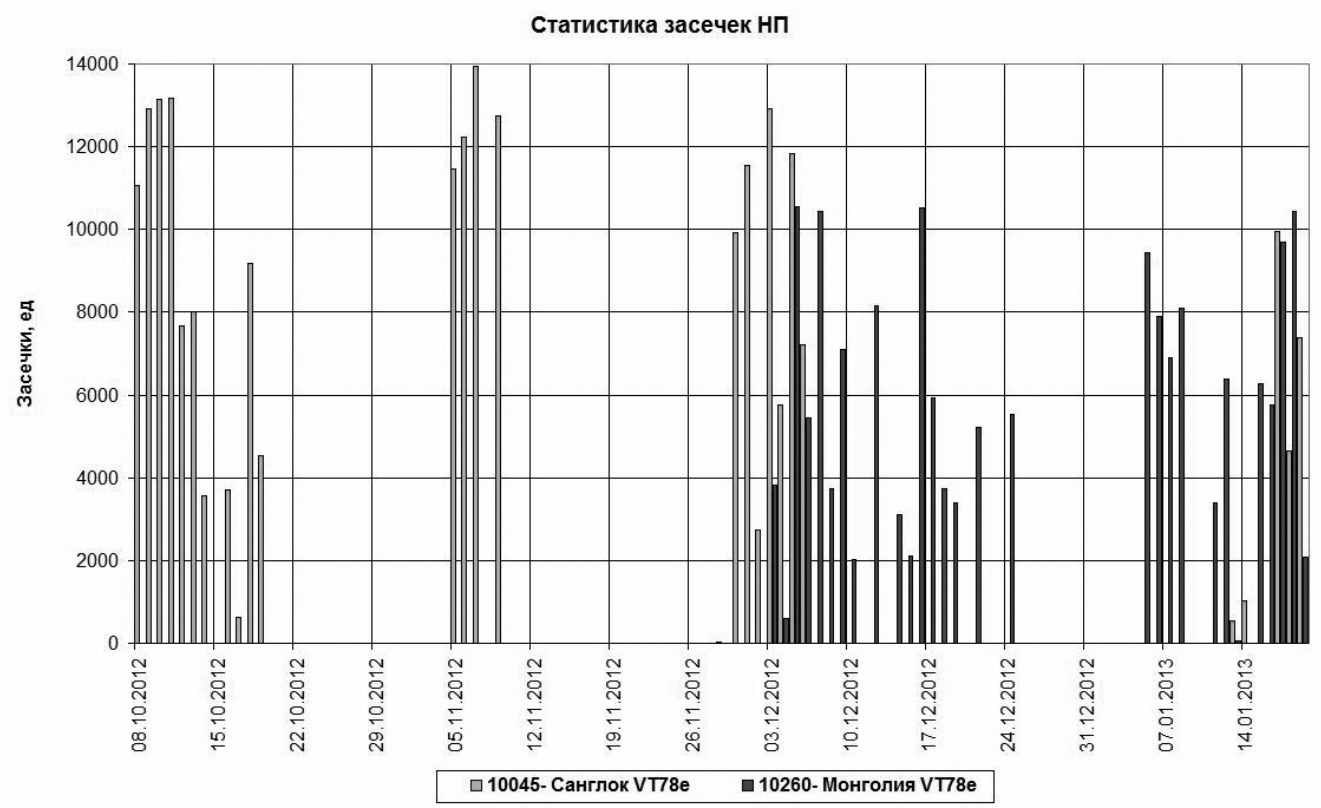

5-р зураг. Хүрэлтогоот ба Санглокын одон орны оргилуудын сансрын обьект илрүүлэлтийн статистик. 


\section{Ашигласан бүтээлийн жагсаалт}

1. И.Молотов, А.Позаненко, Н.Тунгалаг, Г.Даваахуу. Модернизация оптических телескопов в Улан-баторской обсерватории; участие в научной сети оптических инструментов для астрометрических и фотометрических наблюдений (НСОИ АФН). Тезисы докладов 9-ой Российско-Монгольской конференции по астрономии и геофизике. Иркутск, Россия 2011, стр. 4-5.

2. Tungalag N. Study of near-earth objects in Mongolia. Space debris, asteroids and comets. Outreach seminar of 55th session of COPUOS, Vienna, Austria 2012, http://astronomer.ru/

3. I.Molotov et.al. Current status and developments of the ISON optical network. Proceedings of $6^{\text {th }}$ European Conference on Space debris, Darmshtadt, Germany, 22-25 April 2013 